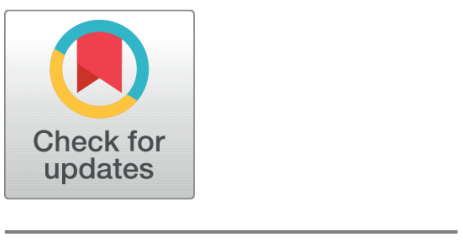

OPEN ACCESS

Received: 18.07.2020

Accepted: 21.08 .2020

Published: 05.10 .2020

Editor: Dr. Natarajan Gajendran

Citation: Adekoya AF, Kofi Nti I (2020) The COVID-19 outbreak and effects on major stock market indices across the globe: A machine learning approach. Indian Journal of Science and Technology 13(35): 3695-3706. https://doi.org/ 10.17485/IJST/v13i35.1180

* Corresponding author.

Tel: +233208736247

ntious1@gmail.com

Funding: None

Competing Interests: None

Copyright: (c) 2020 Adekoya \& Kofi Nti. This is an open access article distributed under the terms of the Creative Commons Attribution License, which permits unrestricted use, distribution, and reproduction in any medium, provided the original author and source are credited.

Published By Indian Society for Education and Environment (iSee)

ISSN

Print: 0974-6846

Electronic: 0974-5645

\section{The COVID-19 outbreak and effects on major stock market indices across the globe: A machine learning approach}

\author{
Adebayo Felix Adekoya ${ }^{1}$, Isaac Kofi $\mathrm{Nti}^{1,2 *}$ \\ 1 Department of Computer Science and Informatics, University of Energy and Natural \\ Resources, Sunyani, Ghana \\ 2 Department of Computer Science, Sunyani Technical University, Sunyani, Ghana. \\ Tel.: +233208736247
}

\section{Abstract}

Background/Objectives: The Coronavirus disease in 2019 (COVID-19) was first seen in Wuhan (capital of Hubei, Chain), and has since spread throughout the world, resulting in the World Health Organisation (WHO) declaring the 201920 coronavirus a pandemic. Its ongoing spread has resulted in a standstill of the world's economy, total lockdown in some counties, closedown of business and firms globally. As of $25^{\text {th }}$ Mar 2020, 11:00 am GMT, a total of 491,280 cases were reported globally. The evolution of COVID-19 and its economic impact on the regional financial markets are highly uncertain, which makes it difficult for legislators to formulate a suitable macroeconomic strategy response. Methods: To ascertain the possible economic impact of COVID-19 globally, this study examines the effect of COVID-19 on major stocks indices across the globe. Using a random sampling technique, we selected thirty (30) world stock market indices in different countries infected with COVID-19 from 31 $1^{\text {st }}$ Dec 2019 to $25^{\text {th }}$ Mar 2020. However, not like a high percentage of previous studies that focus on the regional stock market, we examine the information on daily reported COVID-19 cases and stock market fluctuation over thirty stock market indices that houses the stock prices of several countries around the globe. Also, we estimate the monetary loss within the period, project the future surge of this pandemic on the stock market and outline some portfolio allocation strategies to help the investor hedge against investment risk. Findings: The experimental results in this study show that even a controlled outbreak of the COVID-19 can significantly influence the world's economy in both the short-term and longterm. Our obtained results of COVID-19 associated economic loss echoed in stock prices movements advise that the cost can escalate severely and quickly into global economic stress. Hence, we conclude by outlining some measure that might help investors hedge against such risk using portfolio allocation strategies.

Keywords: Coronavirus; COVID-19; Stock market; stocks price; pandemic; machine-learning; economic impact of COVID-19 


\section{Introduction}

The stock market is one of the financial markets that receive several investments daily due to its associated benefits and gains ${ }^{(1-4)}$. Trillions of dollars are invested in the stock market globally by investors to make a substantial profit, despite its stochastic nature ${ }^{(5)}$. Its stochastic nature is believed to be influenced by several factors ranging from political, economic instability, investors and public sentiments, the board of directors of firms, firms financial status and economic standing ${ }^{(1,2)}$.

Recently, several academic studies have attempted to examine the predictability and influence of these factors on the stock market volatility. The following studies ${ }^{(4,6-9)}$ examined the effect of public sentiment in tweets from Twitter on the stock market volatility. The results from these studies show a higher association between tweets and the stock market. Likewise, ${ }^{(10-12)}$ examined the impact of web financial news on the stock market and revealed that there is a positive linkage between the stock market fluctuations and web news. In the same way ${ }^{(13)}$, reports that there is a positive correlation between discussions on microblogging websites and the stock market. Similarly, ${ }^{(3,14,15)}$ employed historical stock price and macroeconomic variables $^{(16)}$ to forecast the future stock price, using machine learning (ML) algorithms like support vector machines, artificial neural networks and long short term memory. Also, Buhagiar et al. ${ }^{(17)}$ in their study revealed that sports affect the stock market. In other studies ${ }^{(4,18-20)}$, it was shown that google search queries could effectively communicate the volatility of the stock market.

Succinctly, the factors that influence the stock market as already mentioned is extensive. According to Jiang et al. ${ }^{(21)}$, the arrival of new infectious diseases does impend not only human-health but also cause enormous economic loss. McKibbin and Sidorenko examined the effect of pandemic influenza outbreak on the world economy, using a range of scenarios such as mild, moderate, severe and ultra ${ }^{(22)}$. The study outcome shows that a mild case could cause the world $\$$ U330 billion economic loss. Thus, it was indicated that the scale of the pandemic is directly proportional to the economic costs.

Similarly, the daily reported cases of Avian influenza A; thus haemagglutinin $(\mathrm{H})$ seven and the neuraminidase $(\mathrm{N})$ nine (H7N9) cases and stock price indices in China was examined in ${ }^{(21)}$. Using a distributed lag non-linear model, authors describe the variation trend for the stock indices. The study outcome shows that the H7N9 daily reported cases were firmly related to the closing and opening stocks prices. They found that as the number of reported cases increases stocks prices in the biological product, that is Chinese traditional medicine, and the biomedicine sectors decrease. In the same way, the spread of infection and the diffusion of shock over an intra-financial system was examined in ${ }^{(23)}$ and discovered a severe worldwide financial downturn between 2007 and 2008 because of the H1N1 outbreak.

Currently, the outburst of the novel coronavirus disease 2019 (COVID-19), which begun in Wuhan continues to spread rapidly throughout the globe ${ }^{(24-27)}$. As a result, the World Health Organisation (WHO) announced a public health emergency of international concern ${ }^{(28)}$. Though the virus began in China, several cases have been reported lately in different countries ${ }^{(28,29)}$. According to ${ }^{(30)}$ statistics (as of $25^{\text {th }}$ Mar 2020, 11:00 am GMT), a total 491,280 cases were reported globally. Active cases were 351,054 , with $95 \%$ in mild-condition and $5 \%$ in severe or critical condition. One hundred forty thousand, two hundred twentysix $(140,226)$ cases had an outcome; thus, $84 \%$ recovered or discharged from health centres and $16 \%$ deaths. Even though similar viruses such as SARS coronavirus and MERS coronavirus, have hit the world in the past, Liu et al. ${ }^{(31)}$ report that COVID-19 reproductive number is higher compared with the SARS coronavirus.

Therefore, as COVID-19 blow-outs around the world, it has become evident that it can have a grave impact on the world economy ${ }^{(32)}$. Thus, according to behavioural finance, the verdicts of the individual investor to make investments decision is influence by their states to a specific fuzzy ${ }^{(1)}$. Hence, we presume that the global stock market might be severely impacted by changes in investors state due to several cases of reported COVID-19 globally. Besides, based on psychology study, we anticipate that news of an outbreak on a communicable disease like COVID-19, coupled with reported melodramatic news, will stir people to have a negative belief, which might descend to the investment style. Additionally, according to ${ }^{(33)}$, a vital tool for appreciating the impact of events like the emergence of COVID-19 is to consider dynamics in stocks value. As such, the COVID-19 outbreak has brought a significant deal of curiosity on its economic impact on the financial markets.

howsa summary of related works ${ }^{(33-47)}$, specifically in the context of the economic effect of novel COVID-19 on the stock market. We categorised these studies based on the objectives, the period of the dataset and studied stock market. As seen in Table 1 , many previous studies ${ }^{(33,38-47)}$ on the economic effect of the novel COVID-19 on the stock market concentrated on regional stock markets. Only a few ${ }^{(34-37)}$ examine the impact of the novel virus on the global stock market. However, the study by ${ }^{(35)}$ reveals that the decline in stock market returns in a country is proportional to the number of COVID-19 cases reported in the said country. Besides the infection rate, mortality and death rate of the novel virus differ from region to region as reported in the literature ${ }^{(29)}$. Nonetheless, little research exists that attempt to discuss an overall economic effect of the novel (COVID19) infectious diseases on a high percentage of major stocks market indices across the globe. As well, outline some portfolio allocation strategies to help investors hedge against investment risk within this epidemic period. 
Table 1. Summary ofrelated studies

\begin{tabular}{|c|c|c|}
\hline & Period & Region/ stock market index \\
\hline (38) & $\begin{array}{l}\text { 10th Jan to 16th Mar } \\
2020\end{array}$ & China \\
\hline (39) & $\begin{array}{l}\text { 10th Mar - 30th Apr } \\
2020\end{array}$ & Emerging markets in Asian and Europe \\
\hline (40) & $\begin{array}{l}\text { 11th Apr } 2019 \text { to } 9 \text { th } \\
\text { Apr } 2020\end{array}$ & $\begin{array}{l}\text { MSCI World Index, S\&P } 500 \text { FTSE 100, FTSE MIB, IBEX and CSI } \\
300 \text { indices }\end{array}$ \\
\hline (34) & Jan. - April 2020 & $\begin{array}{l}25 \text { stock indices (S\&P } 500 \text { Composite, IBEX 35, FTSE MIB Index, } \\
\text { France CAC 40, DAX } 30 \text { Performance, FTSE ALL SHARE, Shanghai } \\
\text { SE A Share, BIST National 100, Belgium BEL 20, AEX Index, Brazil } \\
\text { Bovespa, S\&P/TSX Composite Index, MOEX Russia Index, Swiss } \\
\text { Market (SMI), Portugal PSI-20, ATX - Austrian Traded Index, } \\
\text { Nifty 500, Israel TA 125, ISEQ All-Share Index, OMX Stockholm } \\
30 \text { (OMXS30), S\&P/BVL General (IGBVL), Korea SE Composite } \\
\text { (KOSPI), NIKKEI } 225 \text { Stock Average, S\&P/CLX IGPA, CLP Index } \\
\text { and WARSAW General Index) }\end{array}$ \\
\hline
\end{tabular}

(41) The month of March S\&P1500

2020

(42) $\quad 31^{\text {st }}$ Dec. $2019-20^{\text {th }} \quad$ China and G7 countries

Mar 2020

(37)

January-April $2020 \quad 75$ countries

(43)

01st Jan $2020-30^{\text {th }} \quad 23$ Countries

Mar 2020

(36)

$4^{\text {th }}$ January 2019 $29^{\text {th }}$ May 2020

Brent Crude Bel 20 index \& USD-EURO IBOVESPA index \& USD-REAL Shanghai Composite Index \& USD-YUAN S\&P/TSX Composite Index \& USD_CAD CAC 40 index \& USD-EURO DAX Index \& USD-EURO S\&P BSE SENSEX index \& USD-RUP FTSE MIB index \&USD-EURO S\&P/BMV IPC index \& USD-PES AMX index \& USD-EURO IMOEX index \& USD-RUB IBEX 35 index \& USD-EURO BIST index \& USD-LiRA, FTSE 100 Index \& USDPOUND S\&P 500 index

(44) $\quad$ 2nd Jan $1900-24^{\text {th }} \quad$ US stock markets

Mar 2020.

Objective
Investigates the effect of
COVID-19 on the Chinese
stock market

examined the impact of the novel virus on developing markets

Examined the impact of COVID-19 on the market value of cryptocurrencies.

Provides commentary on how the stock price - reacted in real-time to different stages in COVID-19's evolution

Investigate the economic effect of the COVID-19 on the US stock market.

Examines the economic constraints in China and G7 countries during the novel COVID19 period.

Demonstrate the reaction of investors to different COVID19 data announcement.

Evaluate the significance of health-news trends during the novel COVID-19 in the predictability of stock returns.

Investigate the impact of COVID-19 on oil-stock prices.

Examine the effect of news related to infectious disease (Spanish Flu, COVID-19) on the stock market. 


\begin{tabular}{|c|c|c|c|}
\hline \multicolumn{4}{|c|}{ Table 1 continued } \\
\hline (35) & $\begin{array}{l}\text { 22nd Jan } 2020-17 \text { th } \\
\text { Apr } 2020\end{array}$ & 64 countries & $\begin{array}{l}\text { Scrutinise the stock markets' } \\
\text { response to the novel COVID- } \\
19 \text { pandemic. }\end{array}$ \\
\hline (45) & $\begin{array}{l}\text { 03rd Feb } 2020 \text { to } \\
17^{\text {th }} \text { Apr } 2020\end{array}$ & DJIA, FTSE 100, DAX, CAC 40, IGBM, and MIB & $\begin{array}{l}\text { Investigating the stock market's } \\
\text { reaction to COVID-19 news in } \\
\text { the six most affected countries. }\end{array}$ \\
\hline (46) & $\begin{array}{l}1 / 1 / 2020 \\
31 / 03 / 2020\end{array}$ & S\&P500 (SP) & $\begin{array}{l}\text { Studies the influence of the } \\
\text { novel COVID-19 on the struc- } \\
\text { ture and degree of risk-return } \\
\text { dependence in the US. }\end{array}$ \\
\hline$(47)$ & Up to $27^{\text {th }}$ Mar 2020 & $\begin{array}{l}\text { US, Italy China, Mainland Spain, Germany, France United King- } \\
\text { dom, Switzerland, Korea, South, Netherlands and Japan Singapore }\end{array}$ & $\begin{array}{l}\text { Map the overall patterns of } \\
\text { country-specific risks and total } \\
\text { risks in the world financial mar- } \\
\text { kets. }\end{array}$ \\
\hline (48) & $\begin{array}{l}\text { 12th Feb } 2020-02 \text { nd } \\
\text { Apr } 2020 \text { using }\end{array}$ & Spain Stock Market (IBEX 35) & $\begin{array}{l}\text { Examine and predict the short- } \\
\text { term of COVID-19 confirmed } \\
\text { cases and IBEX in Spain }\end{array}$ \\
\hline
\end{tabular}

Moreover, as pointed out in ${ }^{(32)}$, the novel COVID-19 might be as transmissible economically as it is medically. Hence, this study attempts to fill in the gap in the literature by examining the extent to which COVID-19 outbreak is affecting the stock markets worldwide. Due to this, we hypothesis that following the anxiety, fear and panic within the initial stage of the COVID19 pandemic, the stock market will movement downwards conferring to the "Model-of-Herd-Behaviour" before getting better to the regular price conferring to the "return-to-the-central" theory ${ }^{(21,49)}$, as investors gain better information and regularise their view on the actual effect of the COVID-19 outbreak.

The remaining sections of this study are organised as follows: Section 2 presents the methods and techniques used in this study. In section 3, we discuss the fallouts of this study and its implications of the global economy. Section 4 presents the conclusion arising from the study.

\section{Methodology}

This section presents the methods and tools adapted for the study.

\subsection{Data flow diagram}

Figure 1 shows the dataflow diagram of the study, which is categorised into three (3) phases. Phase 1 covers study datasets download and integration. In phase 2, we perform data pre-processing, data visualisation and statistical analysis. Finally, we apply a machine learning algorithm under phase 3 to predict stock behaviour in future. We explain in details action taken under each phase in subsequent sections.

\subsubsection{Study Data}

Publicly available data on confirmed COVID-19 cases around the globe as of $25^{\text {th }}$ Mar 2020, 9:49 pm GMT was downloaded from https://www.worldometers.info/coronavirus/coronavirus-cases. The dataset had details of reported COVID-19 cases from all affected countries, which include features like new-cases, new-deaths, total-cases, total-deaths. The stock market indices dataset was download from yahoo finance (https://finance.yahoo.com/world-indices). A total of 30 out of 35 world stock market indices listed were download (from March 2019 to 25th Mar 2020), which captured the open-price (OP), closing price (CP) and volume $(\mathrm{V})$. Details of used indices and individual company stock in this study are shown in Table A.1. We represent stock data $\left(\mathrm{S}_{D}\right)$ on a date $(\mathrm{d})$ as a vector For every stock market data, its quantitative features (OPCP,andV) are represented by $(\mathrm{n})(\mathrm{m})$ $=(\mathrm{d})$ was represented as a vector $(\mathrm{v})=$ feature of COVID-19 dataset and $(\mathrm{d})$ to obtain the combined dataset (d) as the reference key. 


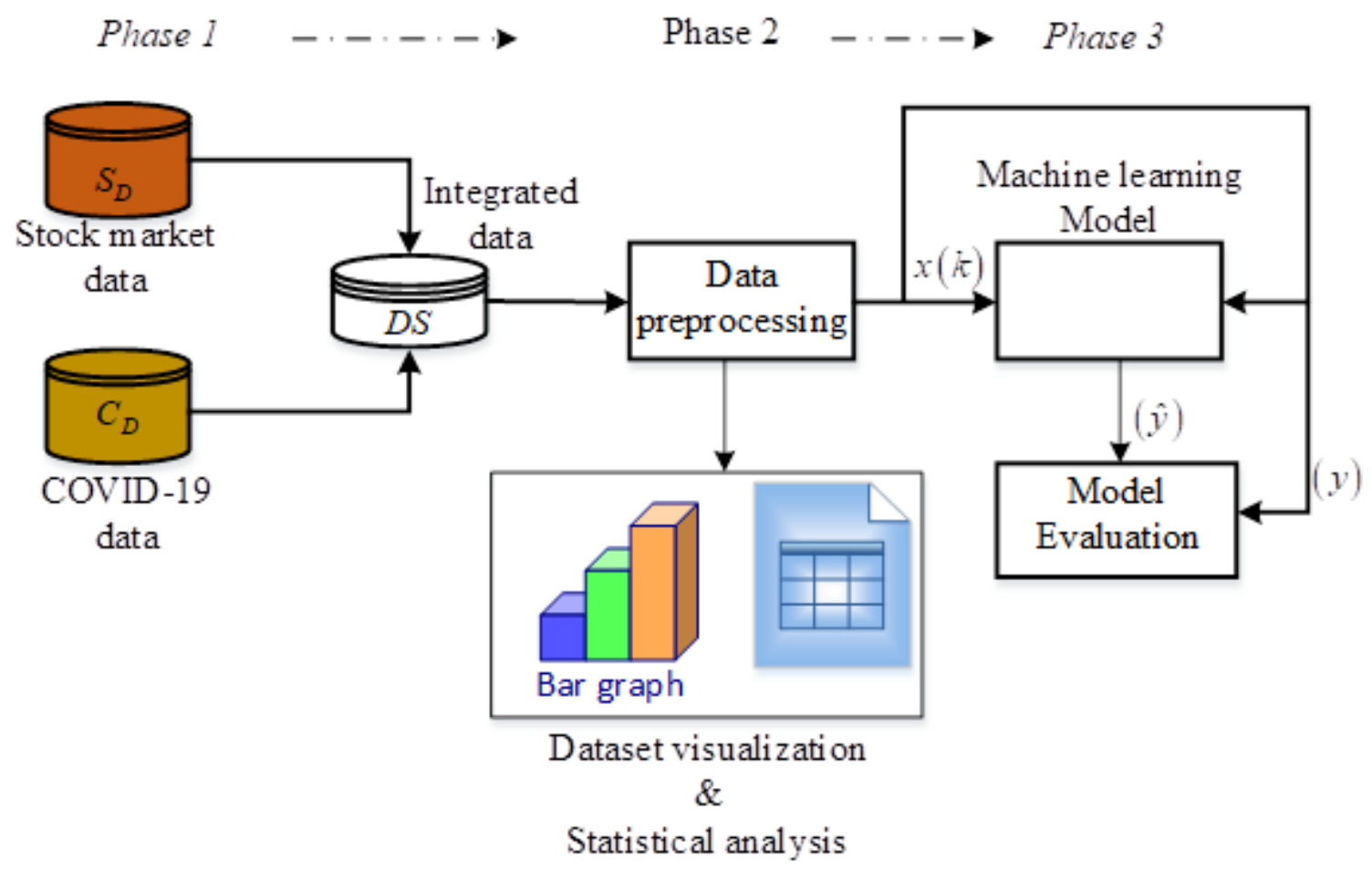

Fig 1. Dataflow diagram of the study

\subsubsection{Data Pre-processing and Visualization}

The combined dataset (DS) was pre-processed in 2-steps: (i) data-cleaning and (ii) data-transformation. At the data-cleaning stage, we replaced missing values within a column (set of features) with the mean value of the said column and removed outliers where needed. A copy of the clean dataset was saved for data visualisation and statistical analysis. For the machine learning model to performed well and fast to reduce computational time, the clean dataset was scaled in the range of $[0,1]$ using the max-min function as defined in Eq. (1). The ANOVA statistical technique was adopted to explore the total effect between cross-basis transformed daily reported cases of COVID-19 and the opening-price, closing-price, and trading volume of the 30 major stock market indices across the globe.

$$
k_{(x)}^{\prime}=\frac{k_{(x)}-k_{(x) \min }}{k_{(x) \max }-k_{(x) \min }}
$$

where $\mathrm{k}_{(\mathrm{x})}^{\prime}$ is the normalized value, $\mathrm{k}_{(x)}=$ the value to be normalised $\mathrm{k}_{(x) \min }$ and $\mathrm{k}_{(x) \operatorname{man}}=$ the minimal and maximum value of the dataset.

\subsection{Machine learning model}

Machine Learning (ML) has extensive business applications throughout several fields, especially in fraud-detection, inventoryplanning, recommendation-engines, image recognition, Amazon's Alexa, supply-chain, financial market analysis and much more. ML focuses on prediction and can make data-analysis resourceful by looking at huge amounts of data simultaneously. Several ML algorithms are applicable for this study; however, we adopted the decision tree (DT) algorithm due to its simplicity but highly efficient, faster training and testing time, which results in low computational cost ${ }^{(2)}$. The "DT is a flow-chart-like tree structure that uses a branching technique to clarify every single likely result of a decision" ${ }^{\text {" }}$. Algorithm 1 explains the operations of the DT algorithm ${ }^{(2,50)}$. The settings of our DT model was, max_depth $=4$ and criterion $=$ entropy. The Scikitlearn library and Python were used to implement the DT model, where the DT was already coded. 
Algorithm 1

1. Estimate the entropy $E(S)$ value of the DS as expressed in Eq.(2).

$$
E(S)=\sum_{i=1}^{m}-p_{i} \log _{2} p_{i}
$$

Where $E(S)=$ entropy of acollection of $D S, m=$ represents the manber of classes in the system and $p i=$ represents the mamber of instances proportion that belongs to class $i$.

2. Calculate the information gain for an attribute $\mathrm{K}$, in a collection $\mathrm{S}$, as expressed in $\mathrm{Eq}(3)$.

where $\mathrm{E}(\mathrm{S})$ represents the entropy of the entire collection and $\mathrm{S}_{u}=$ the set of instances that have value $\mathrm{u}$ for attribute $\mathrm{K}$.

$$
G(S, K)=E(S)-\sum_{u \in \operatorname{values}(K)} \frac{S_{u}}{S} E\left(S_{u}\right)
$$

\subsection{Model Evaluation}

We adopted two (2) closeness evaluation metrics, which ascertain the degree of closeness between the predicted value, namely, root-mean-square-error (RMSE)meanmachine lear ${ }^{(1)}$.

$$
\begin{aligned}
R M S E & =\sqrt{\frac{1}{n}}\left(\sum_{i=1}^{n}\left(y_{i}-\widehat{y}_{i}\right)\right) \\
M A E & =\frac{1}{n}\left(\sum_{i=1}^{n}\left|\frac{y_{i}-\widehat{y}_{i}}{y_{i}}\right|\right)
\end{aligned}
$$

where $\left(\widehat{y}_{i}\right)=$ the predicted value, $\left(y_{i}\right)=$ the actual value and $\mathrm{n}$ is the total number of testing data.

\section{Results and discussions}

We present the results and discussion of the studies under this section.

\subsection{Data Visualisation}

We applied some python code to get a pictorial view of our dataset to gain more understanding of our datasets.

\subsubsection{COVID-19 Dataset}

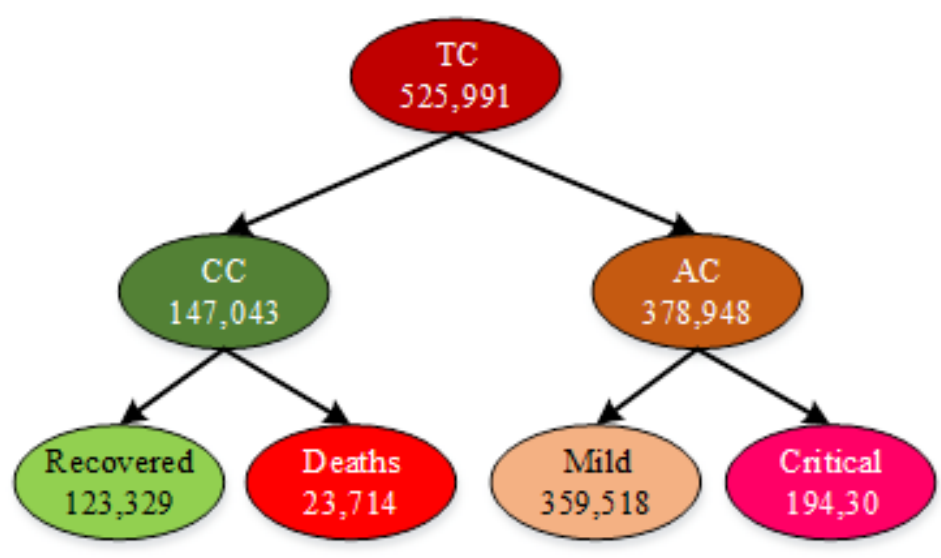

Fig 2. Summary of global COVID-19 cases as of 25th Mar 2020, 11:00 am GMT

Figure 2 shows a pictographic summary of the globally reported cases of COVID-19 as of $25^{\text {th }}$ Mar 2020, 9:49 pm GMT. Out of the total cases (TC) of 491,280, 27.96\% were closed cases (CC); thus, cases that had results and $72.04 \%$ were active cases (AC); 
thus, cases being treated. From Figure 2 it can be said that for every closed COVID-19 case, the recovery rate is approximately $84 \%$ and compared with the death rate of $16 \%$. Furthermore, for cases considered as active, $95 \%$ were in the mild state, while $5 \%$ are in the critical conditions which might lead to death or loss of life. It is important to note that these statistics made here were in respect to our data download on $25^{\text {th }}$ Mar 2020, 9:49 $\mathrm{pm}$ GMT. Hence, possible changes might occur in these values at any time.

\subsubsection{Stock Dataset}

Table A.1 shows the actual name of the used market indices and how we abbreviated them for simplicity. Fig. A.1-A.3 shows a plot of opening price against closing price of world major stock indices used in this study. The aim here was to see the variation in significant stock market indices before and during the COVID-19 pandemic. It was observed that approximate $97 \%$ out of the 30 indices understudy performed well within the second quarter of 2019 through to the first two months of the year 2020. Some indices like Chicago Board Options Exchange (CBOE) Volatility Index (VIX) (see Fig. A.3(I)), recorded low price within the $2^{\text {nd }}$ quarter of 2019 to the first two months in 2020 but saw a sudden rise in the stock price in the third month of 2020. However, while VIX observed a rise in the stock price in the early days of March 2020, most indices (93.3\%) were falling in price. Again, from the visualisation, it can be said that almost (99.3\%) of the listed indices recorded a close relation between opening-prices and close-prices.

The sudden fluctuation in the global indices within the early months of 2020 (see Fig. A.1-A.3) affirms ${ }^{(51,52)}$ reports that the world financial markets have also been responsive to the global economic changes as the world major stock indices have crashed as a result of COVID-19. The intense fluctuations suggest that the longer the COVID-19 pandemic stays, the deeper the world's financial market problems. Furthermore, the observed downfall market indices (see Fig. A.1-A.3) suggest that governments and business decision-makers should look beyond conventional sources of corporate risk and demanding environmental issues.

To further examined the percentage changes in market indices before and during the COVID-19 pandemic, we represent the open price of a market index on $26^{\text {th }}$ Mar 2019 as $\left(O p_{x_{1}}\right)$ in cases where a market index had no value on this day we pick the next day open price. Again, we expressed the open price of a market index on $31^{\text {st }} \mathrm{Dec} 2020$ as $\left(O p_{x_{2}}\right)$, since literature ${ }^{(27,53)}$ shows that it was around this time that marked the beginning of COVID-19 Notwithstanding, if a market index on this date in our dataset the day before closing price. Thus, we assumed that all condition been equal; today's closing price would be tomorrow's open price estimate fall (-) or rise (+) in market indices before the beginning of COVID-19 $\left(\Delta(O P)_{C O \text { VI } D_{B}}\right)$, we express the difference between $\left(O p_{x_{2}}\right)$ and $\left(O p_{x_{1}}\right)$ as a parentage to $\left(O p_{x_{2}}\right)$, as defined in Eq. (6). Similarly, we represent the open price of a market index on the $25^{\text {th }}$ Mar 2020 as $\left(O p_{x_{3}}\right)$ and calculated the change in open prices from the beginning of COVID-19 $\left(O p_{x_{2}}\right)$ to $25^{\text {th }}$ Mar $2020\left(O p_{x_{3}}\right)$ using Eq. (7).

$$
\begin{gathered}
\text { Price change begining of COVID }-19\left(\Delta(\mathrm{OP})_{\mathrm{COVID}_{\mathrm{B}}}\right)=\left(\frac{O P_{x_{2}}-O P_{\mathrm{x}_{1}}}{O P_{\mathrm{x}_{2}}}\right) \times 100 \\
\text { Price change within COVID }-19 \text { period }\left(\Delta(O P)_{\mathrm{COVTD}_{\text {piva }}}\right)=\left(\frac{O P_{x_{3}}-O P_{x_{2}}}{O P_{x_{3}}}\right) \times 100
\end{gathered}
$$

Table 2 shows the summary in market indices fluctuation before COVID-19 and during its peaks period around the world. We observed that at the very beginning of the COVID-19 market indices recorded an average rise in open price within $10.13 \%$ $12 \%$. However, as of $25^{\text {th }}$ Mar 2020, most indices have sharply declined. Approximately $37.4 \%$ compared to the values at the beginning of the COVID-19 pandemic. The weakest markets for this period include NYSE Amex composite index (XAX) at (-) 74.47\%; MERV, (-) 70.55\%; JKSE, (-) 60.73\%; BVSP, (-) 55.46\%; NYA, (-) 43.09\% and RUT at (-) 51.79\%. The VIX saw a rate of return of $(+) 77.64 \%$. The US stock market was among the market that suffered severely from the COVID-19 hit. The huge downfall in the stock price in some indices (see Table 2) shows that the economic impact of COVID-19 is already evident in the countries most affected by the COVID-19 outbreak. The decline in stock price due to COVID-19 is higher than that reported by ${ }^{(54)}$ in years between 1918 and 1920 or 1921 due to similar flu virus outbreaks, due to the rate infection and mortality rate compared with (SARS; 2002-2003) and Middle-East respiratory disorder (MERS; 2012-ongoing) ${ }^{(53)}$.

The dramatic decline in stock price from $31^{\text {st }}$ Dec to $25^{\text {th }}$ Mar can be linked with behavioural economic studies which point out that negative sentiment motivated by nervousness and pessimism affects investment decisions which may also affect asset pricing ${ }^{(21,23,33)}$. Thus, assuming COVID-19 outbreaks generate nervousness and pessimism, COVID-19 would also influence investment decisions and later asset prices. Figures A.4-A.5 shows the plots of stock opening price against COVID-19 infection and mortality rate. 
Table 2. Fluctuations in market indices from March 2019- March 2020

\begin{tabular}{|c|c|c|c|c|c|c|c|}
\hline Market Index & $\left(O p_{x_{1}}\right)$ & $\left(O p_{x_{2}}\right)$ & \multicolumn{2}{|c|}{$\left(\Delta(O P)_{C O V I D_{B}}\right)$} & $\left(O p_{x_{3}}\right)$ & \multicolumn{2}{|c|}{$\left(\Delta(O P)_{\text {COVID }}\right.$ priod $)$} \\
\hline 000001_SS & 3057.56 & 2998.17 & $1.98 \%$ & $(-)$ & 2761.90 & $8.55 \%$ & $(-)$ \\
\hline AORD & 6213.10 & 6921.60 & $10.24 \%$ & $(+)$ & 5006.20 & $38.26 \%$ & $(-)$ \\
\hline AXJO & 6130.60 & 6821.70 & $10.13 \%$ & $(+)$ & 4998.10 & $36.49 \%$ & $(-)$ \\
\hline BFX & 3569.66 & 3993.70 & $10.62 \%$ & $(+)$ & 2853.09 & $39.98 \%$ & $(-)$ \\
\hline BSESN & 37886.29 & 41686.27 & $9.12 \%$ & $(+)$ & 29073.71 & $43.38 \%$ & $(-)$ \\
\hline BUK100P & 12223.47 & 12942.17 & $5.55 \%$ & $(+)$ & 9536.72 & $35.71 \%$ & $(-)$ \\
\hline BVSP & 93668.00 & 116530.00 & $19.62 \%$ & $(+)$ & 74956.05 & $55.46 \%$ & $(-)$ \\
\hline DJI & 25649.56 & 28654.76 & $10.49 \%$ & $(+)$ & 21468.38 & $33.47 \%$ & $(-)$ \\
\hline FCHI & 5271.14 & 6028.96 & $12.57 \%$ & $(+)$ & 4332.79 & $39.15 \%$ & $(-)$ \\
\hline GDAXI & 11374.18 & 13301.43 & $14.49 \%$ & $(+)$ & 9621.24 & $38.25 \%$ & $(-)$ \\
\hline GSPC & 2812.66 & 3240.09 & $13.19 \%$ & $(+)$ & 2457.77 & $31.83 \%$ & $(-)$ \\
\hline GSPTSE & 16138.90 & 17159.60 & $5.95 \%$ & $(+)$ & 12588.10 & $36.32 \%$ & $(-)$ \\
\hline HSI & 28677.76 & 28250.48 & $1.51 \%$ & $(-)$ & 23604.83 & $19.68 \%$ & $(-)$ \\
\hline IMOEX_ME & 2498.60 & 3051.41 & $18.12 \%$ & $(+)$ & 2448.76 & $24.61 \%$ & $(-)$ \\
\hline IPSA & 5193.52 & 5100.91 & $1.82 \%$ & $(-)$ & 5100.91 & $0.00 \%$ & $(+)$ \\
\hline JKSE & 6440.92 & 6329.13 & $1.77 \%$ & $(-)$ & 3937.63 & $60.73 \%$ & $(-)$ \\
\hline KS11 & 2152.98 & 2202.62 & $2.25 \%$ & $(+)$ & 1699.11 & $29.63 \%$ & $(-)$ \\
\hline MERV & 33166.32 & 41681.93 & $20.43 \%$ & $(+)$ & 23890.35 & $74.47 \%$ & $(-)$ \\
\hline MXX & 42695.75 & 44318.90 & $3.66 \%$ & $(+)$ & 34547.58 & $28.28 \%$ & $(-)$ \\
\hline N100 & 1025.72 & 1155.09 & $11.20 \%$ & $(+)$ & 842.25 & $37.14 \%$ & $(-)$ \\
\hline N225 & 21174.34 & 23770.93 & $10.92 \%$ & $(+)$ & 19234.77 & $23.58 \%$ & $(-)$ \\
\hline NASDAQ & 7700.00 & 9004.45 & $14.49 \%$ & $(+)$ & 7421.36 & $21.33 \%$ & $(-)$ \\
\hline NYA & 12598.45 & 13951.26 & $9.70 \%$ & $(+)$ & 9749.80 & $43.09 \%$ & $(-)$ \\
\hline NZ50 & 9574.82 & 11556.45 & $17.15 \%$ & $(+)$ & 9264.38 & $24.74 \%$ & $(-)$ \\
\hline RUT & 1513.76 & 1669.88 & $9.35 \%$ & $(+)$ & 1100.14 & $51.79 \%$ & $(-)$ \\
\hline STOXX50E & 3302.13 & 3780.44 & $12.65 \%$ & $(+)$ & 2765.86 & $36.68 \%$ & $(-)$ \\
\hline TA125-TA & 1397.74 & 1611.26 & $13.25 \%$ & $(+)$ & 1186.70 & $35.78 \%$ & $(-)$ \\
\hline TWII & 10506.68 & 12094.81 & $13.13 \%$ & $(+)$ & 9667.14 & $25.11 \%$ & $(-)$ \\
\hline VIX & 16.22 & 13.74 & $18.05 \%$ & $(-)$ & 61.44 & $77.64 \%$ & $(+)$ \\
\hline $\mathrm{XAX}$ & 2517.25 & 2532.03 & $0.58 \%$ & $(+)$ & 1484.62 & $70.55 \%$ & $(-)$ \\
\hline
\end{tabular}

\subsection{Modelling of the dataset}

Experiencing the fluctuation in stock indices because of the COVID-19 pandemic above we attempt to identify the relationship between each feature (new-cases, new-deaths, total-cases, total-deaths) of COVID-19 dataset and the open price of market indices. Also, predict the next day opening price based on identified features using a regression DT.

Figure 3 shows the feature ranking of the COVID-19 dataset. Features with importance ranking measure values closer to one were taking a highly significant feature. Even though we observed a fall in market indices for the period under study (see Table 2), we observed that the total number of COVID-19 cases and the total mortality (deaths) reported were extremely dominate factors that contributed to the fall in most market index opening price. However, it was further observed that the MOEX Russia Index (IMOEX.ME) responded contrary to total deaths than total cases. We further observed that the market index that recorded significant measure to have an increase or stability on open price.

Out of the feature importance ranking, we selected the two topmost features (total cases, and total deaths) as independent features $(\mathrm{x})$ to predict the next day opening price of a market index. The total cases and mortality reported of COVID-19 was significantly associated with the opening price of most indices (ANOVA F-test average p-value $5.97409 \times 10^{-9}$ ), while the association with the closing price (ANOVA F-test p-value $6.37232 \times 10^{-8}$ ). Figure 4 shows the error measure of the DT regression model. The average RMSE of (0.174) and MAE of (0.353), shows that the model fits well to the dataset. Moreover, since theses metrics measure the degree of closeness between the actual values and the predicted values, based on these results it can be said that the stock market fluctuation can be predicted based on the outbreaks of infectious diseases like the COVID-19. This result affirms ${ }^{(51)}$ study on COVID-19 effects on the world economy and other studies of infection disease (like H7N9, H5N1) and market depreciation ${ }^{(21,22)}$. 


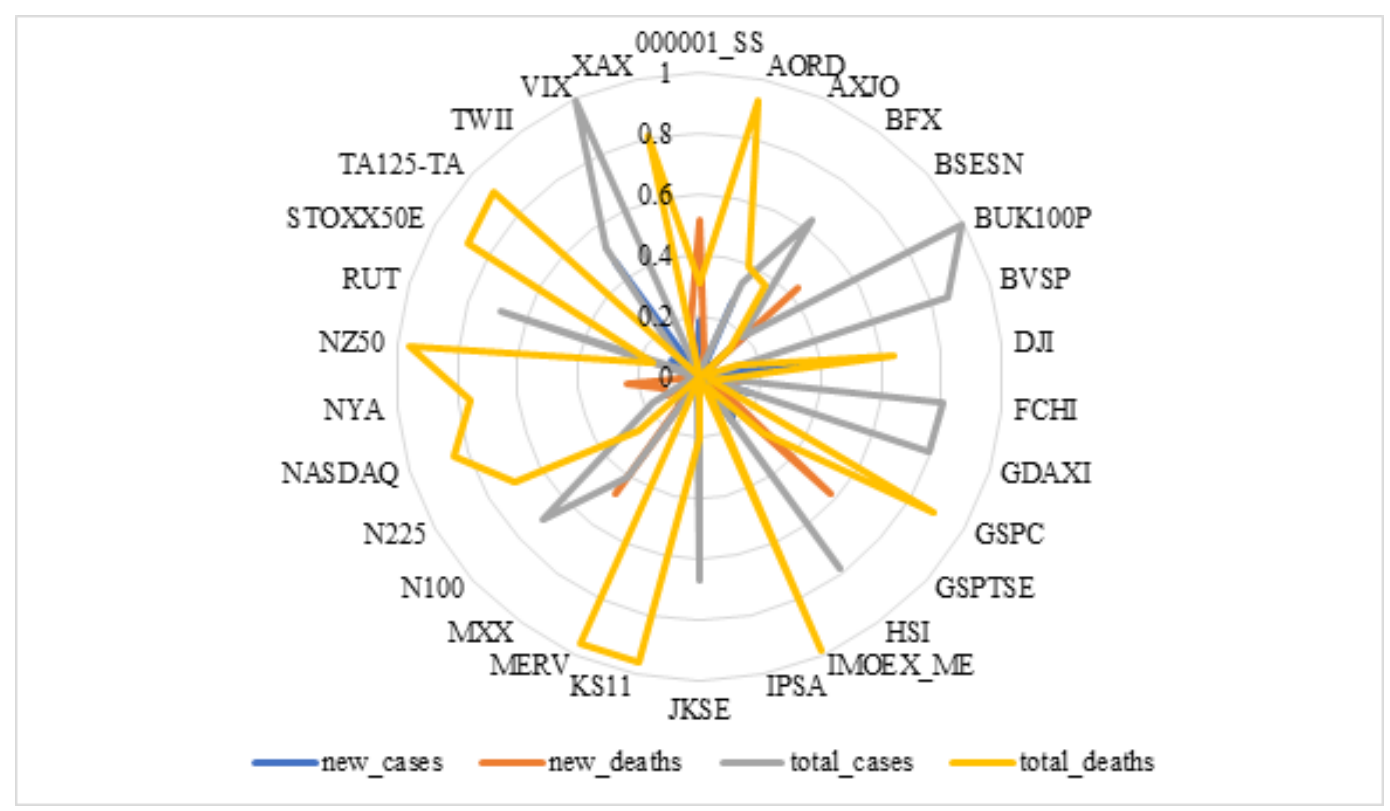

Fig 3. Feature Importance of COVID-19 dataset

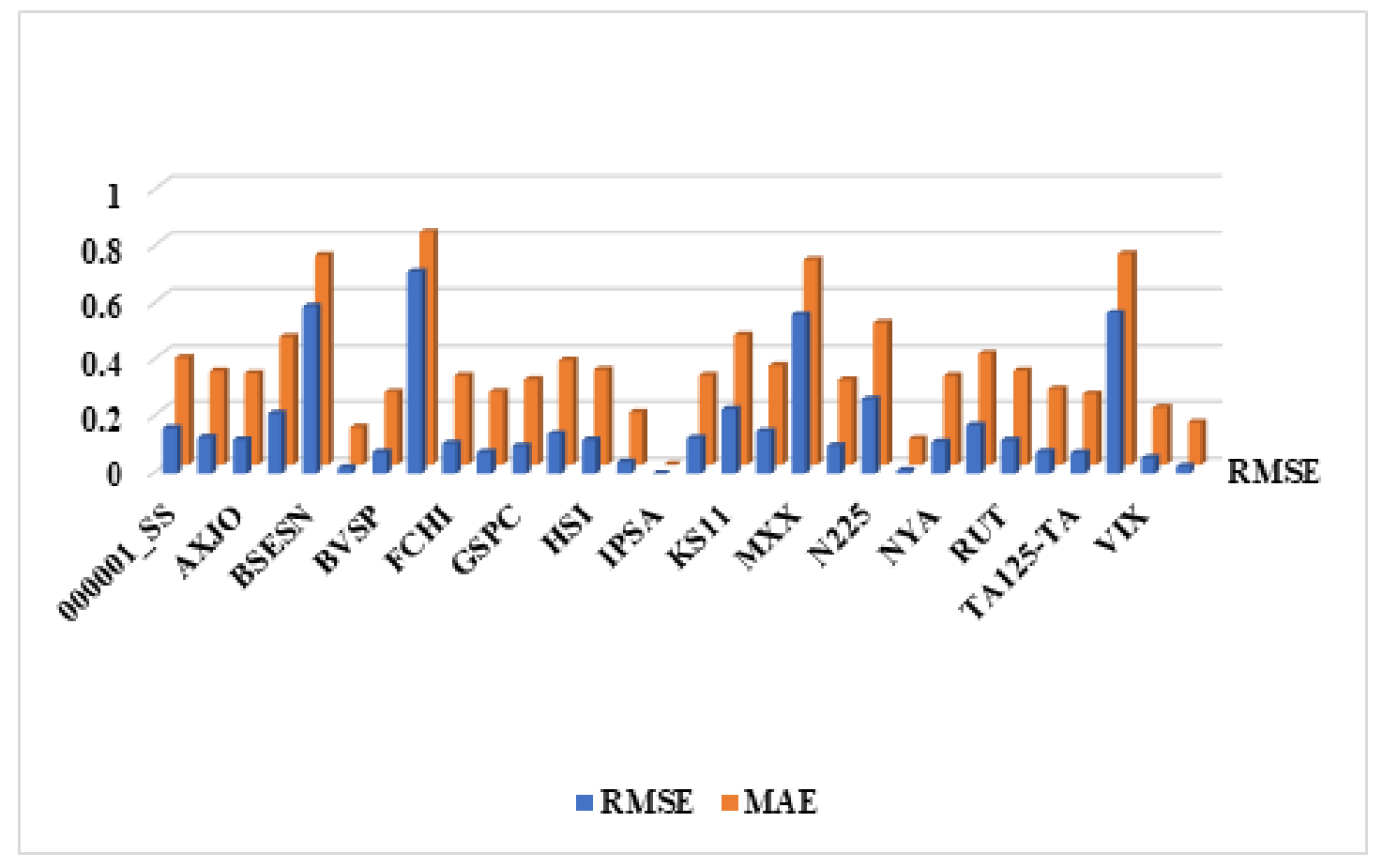

Fig 4. RMSE and MAE of DT model 


\section{Conclusion and recommendation}

Literature has shown that the stock market is affected by several factors; but previous studies were focused on analysing market volatility against public sentiments, historical stock price, financial news, and search engine queries. The global outbreak of COVID-19 has resulted in a standstill of the world's economy, total lockdown in some counties, closedown of business and industries is anticipated to affect the economic strength of countries. As a result, several works of literature ${ }^{(33-47)}$ ascertained the impact of the novel virus on the stock market. However not like a high percentage of these works ${ }^{(33,38-47)}$ that focused on regional datasets, this study presents a comprehensive examination of the information on daily reported COVID-19 cases and stock market fluctuation over thirty stock market indices (see Table 2 ) that houses the stock prices of several countries around the globe using decision tree algorithm. Also, we estimate the monetary loss within the period, project the future surge of this pandemic on the stock market and outline some portfolio allocation strategies to help the investor hedge against investment risk.

This study outcome shows that the stock market is highly associated with COVID-19 pandemic infections and mortality rate. The number of mortality and infection rate reported of COVID cases was also significantly associated with the opening price of the CBOE Volatility Index (VIX). Moreover, the movement of the predicted effect on this index was contrary to all other market indices; thus, it saw proportional to COVID-19 cases, while all others were inversely proportional. Though we do not have a concrete reason why the index was not affected negatively like all others, one reasonable explanation can be attributed to the emergency measurements taken by local governments to deal with COVID-19 together with encouragement by local government to it citizens.

The obtained average measure of RMSE value (0.174) and MAE of (0.353) for all examined indices in this study shows that the stock market is predictable to some extent based on an outbreak of the virus. We conclude that the outbreak of COVID-19 pandemic contributes to economic loss which is echoed in movements in stock prices.

We expected that for affected indices to bounce back, some policy and regulatory frameworks would be needed both in the short-term and coming years. Thus, in the short-term Treasuries and central banks are expected to ensure that mess-up economies remain functioning while the COVID-19 outbreak continues. Furthermore, governments are expected to play a focal part in the face of financial and real stress.

Finally, we recommend the following measures to help investors hedge against the risk of falling prices in this epidemic period using portfolio allocation.

1. As observed in Table 2 , some index has recorded a positive change in opening price; therefore, buying of stocks in defensive businesses is a way for investors to make a profit despite the falling in stock prices. Accordingly, non-cyclical or defensive stocks are securities that mostly do better than the overall market all through bad times, such as COVID-19 pandemic. Thus, they usually provide unswerving stable earnings and dividend, irrespective of the state of the overall market. Firms that produce household non-durables such as toiletries, shampoo, toothpaste, and shaving cream are good examples of defensive firms because the public will still use these items in times of epidemic.

2. Adopting the "Play Dead" syndrome, thus remaining calm and not making any rapid moves. By playing dead, we admonished the investor to put a more substantial portion of their portfolio in money market securities of deposit, such as certificates of deposit, Governments Treasury bills, and fixed instrument or money market instruments which are less volatile as compared to the equity and commodity market in the face of the pandemic.

3. The long-term investor (meaning a time horizon of $10+$ years) are encouraged to take advantage of dollar-cost averaging (DCA) and buying shares regardless of price, thus share price is typically low when the market is down. Over the long run, the cost will "average down," leaving the investor with a better overall entry price for their shares..

4. nvestors can apply the theory of diversification by spreading a percentage of their portfolio between bonds, stocks, cash, and alternative assets. It should be noted that the sharing percentage hinges on factors such as time horizon, risk tolerance, goals and many more. By doing this, the invested is assured of escaping the potentially harmful effects resulting from placing all their eggs in one basket.

5. Another away to hedge against the risk of falling prices in this epidemic period is to go-short. Thus, investors can practice short-selling, by borrowing shares in a firm and selling them- hopeful to purchase them back at a lesser price.

\section{Declaration of interests}

The authors declare that they have no known competing financial interests or personal relationships that could have appeared to influence the work reported in this paper.

Contributors: All authors contributed equally to the development of this paper and have approved the final article.

Funding: Authors did not receive any funding for this study. 


\section{References}

1) Nti IK, Adekoya AF, Weyori BA. A systematic review of fundamental and technical analysis of stock market predictions. Artificial Intelligence Review. 2020;53(4):3007-3057. Available from: https://dx.doi.org/10.1007/s10462-019-09754-z.

2) Nti IK, Adekoya AF, Weyori BA. A comprehensive evaluation of ensemble learning for stock-market prediction. Journal of Big Data. 2020;7(1). Available from: https://dx.doi.org/10.1186/s40537-020-00299-5.

3) Nti IK, Adekoya AF, Weyori BA. Eflcient Stock-Market Prediction Using Ensemble Support Vector Machine. Open Comput Sci. 2020;10:153-163. Available from: https://doi.org/10.1515/comp-2020-0199.

4) Nti IK, Adekoya AF, Weyori BA. Predicting Stock Market Price Movement Using Sentiment Analysis: Evidence From Ghana. Applied Computer Systems. 2020;25(1):33-42. Available from: https://dx.doi.org/10.2478/acss-2020-0004.

5) Bonini S, Swartz S. S. Bonini, S. Swartz, Profits with purpose: How organizing for sustainability can benefit the bottom line, McKinsey Sustain. Resour. Product. 2014. Available from: http://www.mckinsey.com/business-functions/sustainability-and-resource-productivity/our-insights/profitswith-purpose-how-organizing-for-sustainability-can-benefit-the-bottom-line.

6) Pimprikar R, Ramachadran S, Senthilkumar K. Use of machine learning algorithms and twitter sentiment analysis for stock market prediction. Int J Pure Appl Math. 2017;115:521-526. Available from: http://www.ijpam.eu.

7) Checkley MS, Higón DA, Alles H. The hasty wisdom of the mob: How market sentiment predicts stock market behavior. Expert Systems with Applications. 2017;77:256-263. Available from: https://dx.doi.org/10.1016/j.eswa.2017.01.029.

8) Nisar MT, Yeung M. Twitter as a tool for forecasting stock market movements: A short-window event study. The Journal of Finance and Data Science. 2018;4(2):101-119. Available from: https://dx.doi.org/10.1016/j.jfds.2017.11.002.

9) Maknickiene N, Lapinskaite I, Maknickas A. Application of ensemble of recurrent neural networks for forecasting of stock market sentiments. Equilibrium. 2018;13(1):7-27. Available from: https://dx.doi.org/10.24136/eq.2018.001.

10) García-Medina A, Sandoval L, Bañuelos EU, Martínez-Argüello AM. Correlations and Flow of Information between The New York Times and Stock Markets, Physica A. 2018. Available from: https://doi.org/10.1016/j.physa.2018.02.154.

11) Xing ZF, Cambria E, Welsch ER. Intelligent Asset Allocation via Market Sentiment Views. IEEE Computational Intelligence Magazine. 2018;13(4):25-34. Available from: https://dx.doi.org/10.1109/mci.2018.2866727.

12) Zhang X, Qu S, Huang J, Fang B, Yu P. Stock Market Prediction via Multi-Source Multiple Instance Learning. IEEE Access. 2018;6:50720-50728. Available from: https://dx.doi.org/10.1109/access.2018.2869735.

13) Agarwal S, Kumar S, Goel U. Stock market response to information diffusion through internet sources: A literature review. International Journal of Information Management. 2019;45:118-131. Available from: https://dx.doi.org/10.1016/j.ijinfomgt.2018.11.002.

14) Vijh M, Chandola D, Tikkiwal VA, Kumar A. Stock Closing Price Prediction using Machine Learning Techniques. Procedia Computer Science. 2020;167:599-606. Available from: https://dx.doi.org/10.1016/j.procs.2020.03.326.

15) Banik S, Khan AFMK, Anwer M. Hybrid Machine Learning Technique for Forecasting Dhaka Stock Market Timing Decisions. Computational Intelligence and Neuroscience. 2014;2014:1-6. Available from: https://dx.doi.org/10.1155/2014/318524.

16) Nti IK, Adekoya AF, Weyori BA. Random Forest Based Feature Selection of Macroeconomic Variables for Stock Market Prediction. American Journal of Applied Sciences. 2019;16(7):200-212. Available from: https://dx.doi.org/10.3844/ajassp.2019.200.212.

17) Buhagiar R, Cortis D, Newall PWS. Why do some soccer bettors lose more money than others? Journal of Behavioral and Experimental Finance. 2018;18:8593. Available from: https://dx.doi.org/10.1016/j.jbef.2018.01.010.

18) Kim N, Lučivjanská K, Molnár P, Villa R. Google searches and stock market activity: Evidence from Norway. Finance Research Letters. 2019;28:208-220. Available from: https://dx.doi.org/10.1016/j.frl.2018.05.003.

19) Zhong X, Raghib M. Revisiting the use of web search data for stock market movements. Scientific Reports. 2019;9(1):1-8. Available from: https: //dx.doi.org/10.1038/s41598-019-50131-1.

20) Fang J, Wei W, Prithwish C, Nathan S, Feng C, Naren R. Tracking Multiple Social Media for Stock Market Event Prediction. Adv Data Mining Appl Theor Asp 17th ICDM. 2017;p. 16-30. Available from: https://doi.org/0.1007/978-3-319-62701-4_2.

21) Jiang Y, Zhang Y, Ma C, Wang Q, Xu C, Donovan C, et al. H7N9 not only endanger human health but also hit stock marketing. Adv Dis Control Prev. 2017;2. Available from: https://doi.org/10.25196/adcp201711.

22) Mckibbin WJ, Sidorenko AA. Macroeconomic Consequences of Pandemic Influenza, Crawford Sch. Public Policy. Crawford Sch. Public Policy. 2006.

23) Peckham R. Economies of contagion: financial crisis and pandemic. Economy and Society. 2013;42(2):226-248. Available from: https://dx.doi.org/10. 1080/03085147.2012.718626.

24) Rodriguez-Morales AJ, Gallego V, Escalera-Antezana JP, Méndez CA, Zambrano IL, Franco-Paredes C, et al. COVID-19 in Latin America: The implications of the first confirmed case in Brazil. Travel Medicine and Infectious Disease. 2020;35:101613-101613. Available from: https://dx.doi.org/10.1016/j.tmaid. 2020.101613

25) Chen H, Guo J, Wang C, Luo F, Yu X, Zhang W, et al. Clinical characteristics and intrauterine vertical transmission potential of COVID-19 infection in nine pregnant women: a retrospective review of medical records. Lancet. 2020;395:809-815. Available from: https://doi.org/10.1016/S0140-6736(20)30360-3.

26) Chen S, Yang J, Yang W, Wang C, Bärnighausen T. COVID-19 control in China during mass population movements at New Year. The Lancet. 2020;395(10226):764-766. Available from: https://dx.doi.org/10.1016/s0140-6736(20)30421-9.

27) Li Q, Guan X, Wu P, Wang X, Zhou L, Tong Y, et al. Early Transmission Dynamics in Wuhan, China, of Novel Coronavirus-Infected Pneumonia. N Engl JMed. 2020;p. 19-20. Available from: https://doi.org/10.1056/nejmoa2001316.

28) Gallego V, Nishiura H, Sah R, Rodriguez-Morales AJ. The COVID-19 outbreak and implications for the Tokyo 2020 Summer Olympic Games. Travel Medicine and Infectious Disease. 2020;34:101604-101604. Available from: https://dx.doi.org/10.1016/j.tmaid.2020.101604.

29) Xu Z, Shi L, Wang Y, Zhang J, Huang L, Zhang C, et al. Pathological findings of COVID-19 associated with acute respiratory distress syndrome. Lancet Respir Med. 2020;2600:19-21. Available from: https://doi.org/10.1016/S2213-2600(20)30076-X.

30) COVID-19 coronavirus pandemic. 2019. Available from: https://www.worldometers.info/coronavirus/\#countries.

31) Liu Y, Gayle AA, Wilder-Smith A, Rocklöv J. The reproductive number of COVID-19 is higher compared to SARS coronavirus. Journal of Travel Medicine. 2020;27(2):1-4. Available from: https://dx.doi.org/10.1093/jtm/taaa021.

32) Baldwin R, Mauro BWD. Economics in the Time of COVID-19, Graduate Institute, Geneva and CEPR. 2020. Available from: https://cepr.org/sites/ default/files/news/COVID-19.pdf. 
33) Gopinath G. Mitigating the COVID Economic Crisis: Act Fast and Do Whatever It Takes. Baldwin R, di Mauro BW, editors;CEPR Press. 2020. Available from: https://voxeu.org/content/mitigating-covid-economic-crisis-act-fast-and-do-whatever-it-takes.

34) Phan DHB, Narayan PK. Country Responses and the Reaction of the Stock Market to COVID-19-a Preliminary Exposition. Emerging Markets Finance and Trade. 2020;56(10):2138-2150. Available from: https://dx.doi.org/10.1080/1540496x.2020.1784719.

35) Ashraf BN. Stock markets' reaction to COVID-19: Cases or fatalities? Res Int Bus Financ. 2020;54:101249-101249. Available from: https://doi.org/10. 1016/j.ribaf.2020.101249.

36) Salisu AA, Ebuh UG, Usman N. Revisiting oil-stock nexus during COVID-19 pandemic: Some preliminary results. International Review of Economics \& Finance. 2020;69:280-294. Available from: https://dx.doi.org/10.1016/j.iref.2020.06.023.

37) Erdem O. Freedom and stock market performance during Covid-19 outbreak. Financ Res Lett. 2020. Available from: https://doi.org/10.1016/j.frl.2020. 101671.

38) Al-Awadhi AM, Alsaifi K, Al-Awadhi A, Alhammadi S. Death and contagious infectious diseases: Impact of the COVID-19 virus on stock market returns. Journal of Behavioral and Experimental Finance. 2020;27:100326-100326. Available from: https://dx.doi.org/10.1016/j.jbef.2020.100326.

39) Topcu M, Gulal OS. The impact of COVID-19 on emerging stock markets. Financ Res Lett. 2020. Available from: https://doi.org/10.1016/j.frl.2020.101691.

40) Conlon T, Corbet S, McGee JR. Are cryptocurrencies a safe haven for equity markets? An international perspective from the COVID-19 pandemic. Research in International Business and Finance. 2020;54:101248-101248. Available from: https://dx.doi.org/10.1016/j.ribaf.2020.101248.

41) Mazur M, Dang M, Vega M. COVID-19 and the march 2020 stock market crash. Evidence from S\&P1500. Finance Research Letters. 2020;p. 101690101690. Available from: https://dx.doi.org/10.1016/j.frl.2020.101690.

42) Akhtaruzzaman M, Boubaker S, Sensoy A. Financial contagion during COVID-19 crisis. Finance Research Letters. 2020;p. 101604-101604. Available from: https://dx.doi.org/10.1016/j.frl.2020.101604.

43) Salisu AA, Vo XV. Predicting stock returns in the presence of COVID-19 pandemic: The role of health news. International Review of Financial Analysis. 2020;71:101546-101546. Available from: https://dx.doi.org/10.1016/j.irfa.2020.101546.

44) Baker S, Bloom N, Davis S, Kost K, Sammon M, Viratyosin T. The Unprecedented Stock Market Impact of COVID-19. Natl Bur Econ Res. 2020. Available from: https://doi.org/10.3386/w26945.

45) Cepoi CO. Asymmetric dependence between stock market returns and news during COVID-19 financial turmoil. Finance Research Letters. 2020;36. Available from: https://dx.doi.org/10.1016/j.frl.2020.101658.

46) Azimli A. The impact of COVID-19 on the degree of dependence and structure of risk-return relationship: A quantile regression approach. Finance Research Letters. 2020;36. Available from: https://dx.doi.org/10.1016/j.frl.2020.101648.

47) Zhang D, Hu M, Ji Q. Financial markets under the global pandemic of COVID-19. Finance Research Letters. 2020;36. Available from: https: //dx.doi.org/10.1016/j.frl.2020.101528.

48) Ahmar AS, del Val EB. SutteARIMA: Short-term forecasting method, a case: Covid-19 and stock market in Spain. Sci Total Environ. 2020;729:138883138883. Available from: https://doi.org/10.1016/j.scitotenv.2020.138883.

49) Fama FE. Market efficiency, long-term returns, and behavioral financelThe comments of Brad Barber, David Hirshleifer, S.P. Kothari, Owen Lamont, Mark Mitchell, Hersh Shefrin, Robert Shiller, Rex Sinquefield, Richard Thaler, Theo Vermaelen, Robert Vishny, Ivo Welch, and a referee have been helpful. Kenneth French and Jay Ritter get special thanks.1. Journal of Financial Economics. 1998;49(3):283-306. Available from: https://dx.doi.org/10.1016/s0304405x(98)00026-9.

50) Akanbi OA, Amiri IS, Fazeldehkordi E. A Machine-Learning Approach to Phishing Detection and Defense. 2014. Available from: https://doi.org/10. 1016/c2014-0-03762-8.

51) Mckibbin W, Fernando R. The Global Macroeconomic Impacts of COVID-19: Seven Scenarios. Cent Appl Macroecon Anal. 2020;45. Available from: https://ssrn.com/abstract=3547729.

52) Dyer O. Trump claims public health warnings on covid-19 are a conspiracy against him. Bmj. 2020;368. Available from: https://doi.org/10.1136/bmj.m941.

53) Wu Z, Mcgoogan JM. Characteristics of and Important Lessons from the Coronavirus Disease 2019 (COVID-19) Outbreak in China: Summary of a Report of 72314 Cases from the Chinese Center for Disease Control and Prevention. JAMA - J Am Med Assoc. 2020;2019:3-6. Available from: https://doi.org/10.1001/jama.2020.2648.

54) Ursua JF. Pandemics and Depressions, Hist. Shows Swine Flu Could Tak. an Econ. Toll. 2009. 